Www.jmscr.igmpublication.org

Index Copernicus Value: 79.54

ISSN (e)-2347-176x ISSN (p) 2455-0450

crossrefDOI: https://dx.doi.org/10.18535/jmscr/v7i2.142

Journal Of Medical Science And Clinical Research

IGM Publication

An Official Publication of IGM Publication

\title{
Original Research Article \\ Pattern of Internet use and associated factors among adolescents of Rewa City: A Community based Study
}

\author{
Authors \\ Dr Neera Marathe ${ }^{1}$, Dr Achla Jain ${ }^{2 *}$ \\ ${ }^{1}$ Associate Professor, Department of Community Medicine, Shyam Shah Medical College, Rewa \\ Email:neera13@rediffmail.com, Contact No: 9300763779, 7999836769 \\ ${ }^{2} 2^{\text {nd }}$ year Post Graduate Student, Department of Community Medicine, Shyam Shah Medical College, Rewa \\ *Corresponding Author \\ Dr Achla Jain \\ Email:dr.achlajain@gmail.com,Contact No: 9425362920
}

\begin{abstract}
Introduction: Internet is considered as the greatest breakthrough of the century. Although people in all segments of the society use the Internet, especially adolescents are the most frequent users and thus more vulnerable to IA. This research paper explores the prevalence and pattern of internet use among adolescents of Rewa city.

Material and Method: This cross sectional community based study was carried out in Rewa city from January to December 2018. sample size estimated was 418. A multistage random sampling procedure was adopted. 47 subjects of 10 to 19 years age group were selected by simple random sampling from each ward. Thus 423 subjects who gave informed consent and who have been using internet for at least for 3 months were included in the study. Information was collected for sociodemographic variables and pattern of internet usage like purpose, place of access, time, duration per day, money spent per month. Internet addiction test scale developed by Dr. Kimberly Young was used to assess internet addiction.

Percentages and proportion were used.Chi square test of significance was used to find out the association between Internet addiction and variables.

Results: $45.4 \%$ were normal users, $32.1 \%$ had a mild IA, $22.5 \%$ had a moderate addiction but none had severe addiction. Among 423 study subjects $42.8 \%$ were females and $57.2 \%$ were males The majority of study subjects were in the age group of 16 - 19 years. 67.4\%have attained middle school education. Father of 56.2\% study subjects had completed Higher secondary education. Significant association was found between Internet addiction and male gender, increasing age, higher education level, father's education and occupation, nuclear family, staying alone/with friends. Access of internet at home and cyber cafe in Evening and night hours, more than $300 \mathrm{INR} / \mathrm{month}$ spent on internet were found to have significant association with Internet addiction. No association was found between duration of internet use and Mother' education and occupation. Academic purpose (74.9\%) followed by Social networking (67.8\%) was the reasons revealed by study subjects for internet use.

Conclusion: This study's results shows that Internet addiction is a growing public health issue in terms of its prevalence. Internet is becoming an inclusive part of an individual's life.

Keywords: Internet addiction, internet, Young's IAT, India.
\end{abstract}




\section{Introduction}

Internet is considered as the greatest breakthrough of the century. It is a technological tool which makes our life easier and has become an indispensable part of it while its number of user population increases faster each day. ${ }^{[1]}$ Originally devised for information exchange and research purpose, internet has literally percolated every aspect of human life including social communication, education, research, health seeking, banking, business, shopping, administration, and entertainment. So much so that internet has been an essential part of our lives and today, we cannot imagine our lives without internet. $^{[2]}$ India already is the second-largest online market worldwide. In 2017, India had 331.77 million internet users. This figure is projected to grow to 511.89 million internet users in 2022. The majority of India's internet users are mobile phone internet users. ${ }^{[3]}$ Although originally designed to facilitate research among academic and military agencies but over use of it constraints time and often lead to familial, academic and occupational problems. ${ }^{[4]}$

The term "internet addiction" was first proposed by Dr. Ivan Goldberg in 1995 for pathological compulsive internet use. ${ }^{[5]}$ Then, this phenomenon is defined through various terms such as "net addiction", "online addiction", "IA disorder", "pathologic internet use" and "cyber disorder". ${ }^{6]}$. Although people in all segments of the society use the Internet, especially adolescents are the most frequent users and thus more vulnerable to $\mathrm{IA}^{[7,8]}$. Adolescence is considered the most difficult phase in the lifespan of man. It is also the most volatile and unstructured and the most mouldable ${ }^{[9]}$ Period of Adolescence is characterized by developmental changes in physical, psychosocial, emotional and biological domains which make them vulnerable to addiction. ${ }^{[10]}$

There were various studies showing use of internet and internet addiction among college and school students ${ }^{[11-14]}$ As far as community based studies are concerned, there is limited data available regarding use of internet among adolescent in India. Considering the fact the present research paper explores the prevalence and pattern of internet use among adolescents of Rewa city.

\section{Material and Method}

This cross sectional community based study was carried out in Rewa city from January to December 2018 after approval of institutional ethical committee. Primarily this community based study was carried out to find out prevalence of obesity among adolescents with internet use as one of its associated factor. Hence, Sample size was determined by taking combined prevalence of overweight and obesity among adolescents of India found to be $19.3 \%$ by a systematic review of various studies conducted after 2010 with keeping specified relative precision $20 \%$ at $95 \%$ confidence interval . Sample size was estimated according to formula $\mathrm{n}=\mathrm{Z}^{2}{ }_{1-\alpha / 2} \mathrm{p}(1-\mathrm{p}) / \mathrm{d}^{2}$ where $\mathrm{p}$ $=19.3 \%, \mathrm{~d}=20 \%$ of prevalence. ${ }^{[15]}$ Thus, sample size estimated was 418 .

A multistage random sampling procedure was adopted for the selection of study subjects from Rewa city. Ward list was obtained by Municipal Corporation and nine wards were selected randomly. House listing from each selected ward was carried out. 47 subjects of 10 to 19 years age group were selected by simple random sampling from each ward. Thus 423 subjects who gave informed consent and who have been using internet for at least for 3 months were included in the study. Study subjects were assured of confidentiality and anonymity. The data was collected by researcher using semi-structured questionnaire consisting of information about demographic data, information about internet usage like purpose of internet use, place of access (home, cybercafé, or institution), the time when the internet is accessed the most and the average duration of being online per day, money spent per month . Internet addiction test scale developed by Dr. Kimberly Young was used with slight modification to assess internet addiction. ${ }^{[16]}$ Young's internet addiction test is a self-rated scale 
developed for screening and measuring level of internet addiction and has been used extensively for this purpose worldwide. It contains twenty questions related to internet usage to be scored on Likert scale from 1 (rarely) to 5 (always). According to Young's criteria, total IAT scores 20-39 represent average users with complete control of their internet use, scores 40-69 represent over users with frequent problems caused by their internet use, and scores 70-100 represent internet addicts with significant problems caused by their internet use. A total score of $<20$ represent normal user.

Data was entered in Microsoft Excel spread sheet, analysed and interpreted using Descriptive statistics. Chi square test of significance was used to find out the association between Internet addiction and sociodemographic variables at $<.05$ significance level.

\section{Results and Discussion}

Table 1 shows association of Socio demographic characteristics and internet addiction of study subjects. Among 423 study subjects 181(42.8\%) were females and $242(57.2 \%)$ were males The majority of study subjects were in the age group of $16-19$ years. Around two third of the study subjects have attained middle school education and studying in higher classes and colleges. Father of more than half of study subjects had completed Higher secondary education. The study revealed that $45.4 \%$ were normal users, $32.1 \%$ had a mild IA, $22.5 \%$ had a moderate addiction but none had severe addiction. Studies have shown that internet addiction is a worldwide phenomenon and its prevalence varied greatly from $03 \%$ to $38 \%$ depending on the population studied, methodology of the study, and diagnostic criteria used. ${ }^{[17]}$ Though a community based study but prevalence of internet addiction was comparable with many institution based study having school and college students as study participants ${ }^{[14,18]}$ The association between the level of IA and their demographic variables were shown in Table 2. Internet addiction was found to be a significantly associated with male gender, higher age group, increasing level of education, fathers education and occupation. This is in accordance with the other studies. ${ }^{[12,13,14,18]}$ Higher educational status of father tends to be associated with internet addiction among study subjects. Subjects whose fathers were in service and having business were found to have more internet addiction as compared to those whose father's were laborer/ unemployed. No significant association was found with Mother's education and occupation. Similar pattern was observed in the study done by Kayastha $B$ et $\mathrm{al}^{[19]}$ Arthanari $\mathrm{S}$ et al also corroborates the finding of not significant association between Internet Addiction and mother's and father's educational status ${ }^{[13]}$ Study revealed highly significant association between Internet Addiction and Staying away from family. Similar finding was revealed in other study by Chaudhari $\mathrm{B}$ et $\mathrm{al}^{[14]}$ Internet addiction was present in those subjects having nuclear family and this association was found to be significant. The reasons might be loneliness, boredom, privacy and lack of supervision of parents, ample time available experienced by subjects staying away from family or having nuclear family. However Kayastha Bet al found no significant association with types of family and presently residing status.

Table 3 shows pattern of internet use among study subjects. Use of Internet was found mostly in evening and night hours 304(71.9\%) as compared to mornings and afternoon 119 (28.1\%). Home $262(62 \%)$ was found to be most common place of accessing internet followed by cyber café 97 (22.9\%) and workplace/ institution 64 (15.1\%) . As far as duration of being online, present study revealed,291( 68.8\%) subjects use internet for 1-2 per day followed subjects who were using it more than 2 hrs 81(19.2\%) More than half of the subjects were having monthly expenditure of 300 to 500 INR. Study subjects gave multiple responses for purpose of using internet. Almost three fourth subjects use the internet for academic purposes followed by social networking (68\%), 
chatting (53\%), emailing(47\%), Gaming(57\%), and downloading media files(34\%) .

Table 4 shows association of Internet addiction and pattern of its use among study subjects. Internet addiction was found to be significantly associated with evening and night hours; where place of access is home and cyber café; and monthly expenditure on internet more than 300 INR. Similar findings were reported in other studies $^{[12,13,14]}$

Table: 1 Sociodemographic characteristics of Study Subjects

\begin{tabular}{|c|c|c|}
\hline Sociodemographic Profile of study subjects & $\operatorname{No}(n=423)$ & Percentage \\
\hline \multicolumn{3}{|l|}{ Gender } \\
\hline Male & 242 & 57.2 \\
\hline Female & 181 & 42.8 \\
\hline \multicolumn{3}{|l|}{ Age } \\
\hline 10-15 years & 136 & 32.2 \\
\hline 16-19 years & 287 & 67.8 \\
\hline \multicolumn{3}{|l|}{ Education attained } \\
\hline Illiterate and primary School completed & 53 & 12.5 \\
\hline $6^{\text {th }}$ to $8^{\text {th }}$ class & 85 & 20.1 \\
\hline $9^{\text {th }}$ to $12^{\text {th }}$ & 209 & 49.4 \\
\hline Pursuing Graduation & 76 & 18.0 \\
\hline \multicolumn{3}{|l|}{ Father's Education } \\
\hline Primary completed & 87 & 20.6 \\
\hline Middle and High School Completed & 98 & 23.2 \\
\hline Higher Secondary Completed & 102 & 24.1 \\
\hline Graduate and above & 136 & 32.1 \\
\hline \multicolumn{3}{|l|}{ Mother's Education } \\
\hline Primary completed & 50 & 11.8 \\
\hline Middle and High School Completed & 53 & 12.5 \\
\hline Higher Secondary Completed & 223 & 52.7 \\
\hline Graduate and above & 97 & 23.0 \\
\hline \multicolumn{3}{|l|}{ Father' Occupation } \\
\hline Govt Service & 56 & 13.2 \\
\hline Private Service & 96 & 22.7 \\
\hline Self employed/ Business & 118 & 27.9 \\
\hline Labourer and Agriculture work laborer & 102 & 24.1 \\
\hline unemployed & 51 & 12.1 \\
\hline \multicolumn{3}{|l|}{ Mother's Occupation } \\
\hline Govt Service & 38 & 9 \\
\hline Private Service & 63 & 14.9 \\
\hline Self employed/ Business & 96 & 22.7 \\
\hline Labourer and Agriculture work labourer & 74 & 17.5 \\
\hline Unemployed/ Homemaker & 152 & 35.9 \\
\hline \multicolumn{3}{|l|}{ Type of Family } \\
\hline Joint & 234 & 55.3 \\
\hline Nuclear & 189 & 44.7 \\
\hline \multicolumn{3}{|l|}{ Residence } \\
\hline Staying with family & 365 & 86.3 \\
\hline Far away with family/ Hostel/ With friends & 58 & 13.7 \\
\hline \multicolumn{3}{|l|}{ Type of Internet User } \\
\hline Normal & 192 & 45.4 \\
\hline Mild & 136 & 32.1 \\
\hline Moderate & 95 & 22.5 \\
\hline Severe & 00 & 00 \\
\hline
\end{tabular}


Table 2: Association of Sociodemographic characteristics and Internet Addiction

\begin{tabular}{|c|c|c|c|c|c|}
\hline $\begin{array}{l}\text { Sociodemographic } \\
\text { characteristics }\end{array}$ & $\begin{array}{c}\text { Normal (192) } \\
(\%)\end{array}$ & Mild(136) (\%) & Moderate(95) (\%) & $\begin{array}{c}\text { Chi Square } \\
\text { statistic }\end{array}$ & $\mathrm{P}$ value \\
\hline \multicolumn{6}{|l|}{ Gender } \\
\hline Male (242) & $102(42.2)$ & $75(31)$ & $65(26.8)$ & 6.4228 & .0403 \\
\hline Female (181) & $90(49.7)$ & $61(33.7)$ & $30(16.6)$ & & \\
\hline \multicolumn{6}{|l|}{ Age } \\
\hline $10-15(136)$ & $78(57.4)$ & $30(22.1)$ & $28(20.5)$ & 12.9824 & .001517 \\
\hline $16-19(287)$ & 114(39.7) & 106(36.9) & $67(23.4)$ & & \\
\hline \multicolumn{6}{|l|}{ Education Attained } \\
\hline $\begin{array}{l}\text { Illiterate and primary } \\
\text { School completed (53) }\end{array}$ & $35(66.0)$ & $10(18.9)$ & $8(15.1)$ & 28.5672. & .000073 \\
\hline $6^{\text {th }}$ to $8^{\text {th }} \operatorname{class}(85)$ & $51(60.0)$ & $22(25.9)$ & $12(14.1)$ & & \\
\hline $9^{\text {th }}$ to $12^{\text {th }}(209)$ & $85(40.7)$ & $71(40.0)$ & $53(25.3)$ & & \\
\hline $\begin{array}{ll}\text { Pursuing } & \text { Graduation } \\
\text { (76) } & \end{array}$ & $21(27.6)$ & $33(43.4)$ & $22(30.0)$ & & \\
\hline \multicolumn{6}{|l|}{ Father' Occupation } \\
\hline Govt Service (56) & $20(35.7)$ & $20(35.7)$ & $16(28.6)$ & 26.1813 & .000978 \\
\hline Private Service(96) & $36(37.5)$ & $33(34.4)$ & $27(28.1)$ & & \\
\hline $\begin{array}{l}\text { Self employed/ Business } \\
\text { (118) }\end{array}$ & $51(43.2)$ & $32(27.1)$ & $35(29.7)$ & & \\
\hline $\begin{array}{lr}\text { Labourer } & \text { and } \\
\text { Agriculture } & \text { work } \\
\text { labourer(102) } & \\
\end{array}$ & $52(51.0)$ & $40(39.2)$ & $10(9.8)$ & & \\
\hline Unemployed(51) & $33(64.7)$ & $11(21.6)$ & $7(13.7)$ & & \\
\hline \multicolumn{6}{|l|}{ Father's Education } \\
\hline Primary completed(87) & $53(60.9)$ & $24(27.6)$ & $10(11.5)$ & 21.8395 & .001295 \\
\hline $\begin{array}{l}\text { Middle and High School } \\
\text { Completed(98) }\end{array}$ & $49(50.0)$ & $34(34.5)$ & $15(15.3)$ & & \\
\hline $\begin{array}{l}\text { Higher Secondary } \\
\text { Completed(102) }\end{array}$ & $36(35.3)$ & $33(32.4)$ & $33(32.3)$ & & \\
\hline $\begin{array}{ll}\text { Graduate } & \text { and } \\
\text { above }(136) & \\
\end{array}$ & 54(39.7) & $45(33.1)$ & $37(27.2)$ & & \\
\hline \multicolumn{6}{|l|}{ Residence } \\
\hline $\begin{array}{ll}\text { Staying } & \text { with } \\
\text { family(365) } & \end{array}$ & $182(49.9)$ & $117(32.0)$ & $66(18.1)$ & 34.4433 & $<0.00001$ \\
\hline $\begin{array}{l}\text { Far away with family/ } \\
\text { Hostel/ With friends }(58)\end{array}$ & $10(17.2)$ & 19(32.8) & $29(50.0)$ & & \\
\hline \multicolumn{6}{|l|}{ Mother's Occupation } \\
\hline Govt Service (38) & $14(36.8)$ & $12(31.6)$ & $12(31.6)$ & 7.9646 & .436931 \\
\hline Private Service (63) & $23(36.5)$ & $21(33.3)$ & $19(30.2)$ & & \\
\hline $\begin{array}{l}\text { Self employed/ Business } \\
\text { (96) }\end{array}$ & $45(46.9)$ & $34(35.4)$ & $17(17.7)$ & & \\
\hline $\begin{array}{lr}\text { Labourer } & \text { and } \\
\text { Agriculture } & \text { work } \\
\text { labourer (74) } & \\
\end{array}$ & $39(52.7)$ & $20(27.0)$ & $15(20.3)$ & & \\
\hline $\begin{array}{l}\text { Unemployed/ } \\
\text { Homemaker (152) }\end{array}$ & 71(46.7) & $49(32.2)$ & $32(21.1)$ & & \\
\hline \multicolumn{6}{|l|}{ Mother's Education } \\
\hline Primary completed(50) & $18(36.0)$ & $16(32.0)$ & $16(32.0)$ & 7.4037 & .28512 \\
\hline $\begin{array}{l}\text { Middle and High School } \\
\text { Completed(53) }\end{array}$ & $23(43.4)$ & $17(32.1)$ & $13(24.5)$ & & \\
\hline $\begin{array}{l}\text { Higher } \quad \text { Secondary } \\
\text { Completed (223) }\end{array}$ & $98(44.0)$ & $78(35.0)$ & $47(21)$ & & \\
\hline Graduate and above (97) & $53(54.6)$ & $25(25.8)$ & 19(19.6s) & & \\
\hline \multicolumn{6}{|l|}{ Type of Family } \\
\hline Joint (234) & 121(51.7) & $58(24.8)$ & $55(23.5)$ & 13.6982 & .00106 \\
\hline Nuclear(189) & $71(37.6)$ & $78(41.3)$ & $40(21.1)$ & & \\
\hline
\end{tabular}

Significant at $\mathrm{p}<.05$ 
Table 3 : Pattern of Internet Use among Study Subjects

\begin{tabular}{|l|c|c|}
\hline Characteristics Of Internet use & NO $(\mathrm{n}=423)$ & Percentage \\
\hline Time of internet use & & \\
\hline Morning & 30 & 7.1 \\
\hline Afternoon & 89 & 21.0 \\
\hline Evening and Night & 304 & 71.9 \\
\hline Place of Access & 262 & \\
\hline Home & 97 & 62.0 \\
\hline Cyber cafe & 64 & 15.9 \\
\hline Institute(school/college/workplace) & & \\
\hline Duration (being online) & 51 & 12.1 \\
\hline Less than an hour & 291 & 68.8 \\
\hline 1-2 hrs & 81 & 19.1 \\
\hline More than 2 hrs & & \\
\hline Monthly expenditure on internet(INR) & 122 & 28.8 \\
\hline More than 300 & 301 & 71.2 \\
\hline Less than 300 & & \\
\hline Purpose of Internet Use* & 317 & 74.9 \\
\hline Academic purpose & 287 & 67.8 \\
\hline Social Networking & 225 & 53.2 \\
\hline Chatting & 241 & 57.0 \\
\hline Gaming & 199 & 47.0 \\
\hline Emailing & 144 & 34.0 \\
\hline Download media files &
\end{tabular}

*Multiple response

Table 4: Association of Pattern of internet use and Internet Addiction

\begin{tabular}{|l|c|c|c|c|c|}
\hline & Normal & Mild & Moderate & & \\
\hline Most Common time & & & & & \\
\hline Morning and afternoon hrs (119) & $71(58.8)$ & $35(29.3)$ & $13(10.9)$ & 17.6276 & .000149 \\
\hline Evening and night hrs (304) & $121(39.8)$ & $101(33.2)$ & $82(27.0)$ & & \\
\hline Most Common Place of Access & & & & & \\
\hline Home (262) & $115(43.9)$ & $79(30.2)$ & $68(25.9)$ & 21.5798 & .000243 \\
\hline Cyber café (97) & $35(36.1)$ & $45(46.4)$ & $17(17.5)$ & & \\
\hline $\begin{array}{l}\text { Institute(school/college/workplace) } \\
\text { (64) }\end{array}$ & $42(65.6)$ & $12(18.7)$ & $10(15.6)$ & & \\
\hline Duration (being online) & & & & & \\
\hline Less than an hour(51) & $24(47.1)$ & $18(35.3)$ & $09(17.6)$ & 1.3275 & .856694 \\
\hline 1-2 hrs(291) & $132(45.4)$ & $94(32.3)$ & $65(22.3)$ & & \\
\hline More than 2 hrs(81) & $36(44.4)$ & $24(29.6)$ & $21(26.0)$ & & \\
\hline $\begin{array}{l}\text { Monthly expenditure } \\
\text { internet(INR) }\end{array}$ & & & & & \\
\hline More than 300 (122) & $42(34.4)$ & $54(44.3)$ & $26(21.3)$ & 12.4625. & .001967. \\
\hline Less than300 (301) & $150(49.8)$ & $82(27.2)$ & $69(22.9)$ & & \\
\hline
\end{tabular}

\section{Conclusion and Recommendations}

Present study revealed prevalence of internet addiction as $54.6 \%$. However severe internet addiction was not found among study subjects. This study's results shows that Internet addiction is a growing public health issue in terms of its prevalence right from the early age. Day by day, Internet is becoming an inclusive part of an individual's life. Its association with demographic variables like Male gender, higher class, father's occupation gives an idea about group which can be targeted for interventions like counselling, promoting outdoor activities, games. Moreover study revealed high prevalence of internet addiction in those subjects staying alone and far away from their family. Special programs might be organized for them which promote social interaction with the residing community. Educational institutions can play a pivotal role in engaging students in extracurricular activities. 
Association of Internet addiction was found with home as place of access, during evening \& night hrs and monthly expenditure. In this context, an effective supervision of parents might help in curtailing internet activity of adolescents.

\section{Limitations}

In this cross sectional study we found factors associated with internet addiction, but impact of Internet addiction on health and mental status of study subjects could not be established. An observational, longitudinal study would give more information about effect of internet addiction on social and mental status of adoloscents.

\section{References}

1. Aboujaoude E, Koran L. M., Gamel N, Large M. D., Serpe R. T.: Potential markers for problematic Internet use: a telephone survey of 2,513 adults. CNS Spectr 2006, $11: 750-755$.

2. Neha Alawadhi, IAMAI report. ET Bureau Sep 3, 2015. Available form: http://articles.economictimes.indiatimes.co m/2015-09-03/news/66178659_1_userbase-iamaiinternet-and-mobile-association

3. Number of internet users in India from 2015 to 2022 (in millions) Available from https://www.statista.com/statistics/255146/ number-of-internet-users-in-india/ accessed on 25.1.2019

4. Young KS. Internet addiction: symptoms, evaluation and treatment. In: VandeCreek L, Jackson TL (Eds.).Innovations in clinical practice: A Source book. Sarasota, FL: Professional Resource Press; 1999; 17:19

31.

http://www.netaddiction.com/articles/sym ptoms.pdf

5. Goldberg I. Internet Addiction 1996. Available from: http://web.urz. uniheidelberg.de/Netzdienste/anleitung/w wwtips/8/addict.html [accessed on 25.1.2019].
6. Korkmaz O, Sahin C, Usta E (2011) The relationship between interaction and audience anxiety levels and internet addiction of adults. Contemporary Educ Technol 2: 200-212

7. Sadock BJ, Sadock VA. Kaplon and Sadock Comprehensive Textbook of Psychiatry. 9th ed. Philadelphia: Lippincott Williams and Wilkins; 2009.

8. Ha HJ, Kim YS, Bae SC, Kim H, Sim M (2007) Depression and Internet Addiction in Adolescents. Psychopathology 40: 424430.

9. Gayathri Rao, Dr. Ankur Madan. A Study Exploring the Link between Attachment Styles and Social Networking Habits of Adolescents in Urban Bangalore. International Journal of Scientific and Research Publications, Volume 3, Issue 1, January 2013 Page 1-12 .

10. Barnett NP, Monti PM, Wood MD (2001) Motivational Interviewing for AlcoholInvolved Adolescents in the Emergency Room. In: Wagner EF, Waldron HB (eds.) Innovations in Adolescent Substance Abuse Interventions. Pergamon: Oxford 143-168.

11. Kandell JJ. Internet addiction on campus: The vulnerability ofcollege students. Cyberpsychol Behav 1998;1:11- 7.

12. Goel D, Subramanyam A, Kamath R. A study on the prevalence of internet addiction and its association with psychopathology in Indian adolescents. Indian J Psychiatry 2013;55:140-3.

13. Arthanari S, Khalique N, Ansari MA, Faizi N. Prevalence \& determinants of Internet Addiction among Indian adolescents. Indian J Comm Health. 2017; 29, 1: 89-95

14. Chaudhari B, Menon P, Saldanha D, Tewari A,Bhattacharya L. Internet addiction and its determinants among medical students. Ind Psychiatry J 2015;24:158-62. 
15. Ranjani H, Mehreen T.S., Pradeepa Rajendra, Anjana Ranjit Mohan, Garg Renu, Anand Krishnan \& Viswanathan Mohan, Epidemiology of childhood overweight \& obesity in India: A systematic review, Indian J Med Res 143, February 2016, pp 160-174

16. Young K, Christiano NA. Assesment of Internet Addiction Centre for Internet Addiction Recovery. Available from http://www.icsao.org/fileadmin/Divers_pa piers/KYounginternetaddiction5.pdf. [accessed on 13.8.2018]

17. Chakraborty K, Basu D, Vijaya Kumar KG. Internet addiction: Consensus, controversies, and the way ahead. East Asian Arch Psychiatry 2010;20:123- 32.

18. Surwase K, Bagdey P, Adikane H. Prevalence and Associated Risk Factors of Internet Addiction in College Going Students in Nanded city. Natl J Community Med 2017; 8(5):213-218.

19. Kayastha B, Gurung A, Chawal R (2018) A Descriptive Study to Assess the Level of Internet Addiction among Adolescents: A Case Study of High Schools in Mangalore. J Child Adolesc Behav 6: 378. doi:10.4172/2375-4494.1000378. 